\title{
MulawarmanLawReview
}

\section{Instrumen Kontrak dalam Pembangunan Centre Point of Indonesia}

\author{
Muhammad Wahyu, Mustafa Bola, Harustiati A.Moein, Muhammad Ilham Arisaputra
}

Fakultas Hukum, Universitas Hasanuddin, Indonesia.

Email: wahyuhippmas@gmail.com

\begin{abstract}
This study aims to analyze the arrangement of the use of contract instruments in the construction of the Center Point of Indonesia (CPI) in Makassar City. This research is a normative study using a statutory approach and a conceptual approach. The results showed that the regulation of the use of contract instruments in the construction of the Center Point of Indonesia (CPI) in Makassar was made possible by legislation, namely Law Number 30 of 2014 concerning Government Administration, Law Number 23 of 2014 concerning Regional Government, and Law Number 27 Year 2007 jo. Law Number 1 of 2014 and Management of Coastal Areas and Small Islands. The contract intended in this context is a public contract because one of the parties is the Provincial Government of South Sulawesi. The responsibility of the parties to the contract for the construction of the Center Point of Indonesia (CPI) in Makassar City arises from the existence of the rights and obligations of each party stipulated in the Agreement. In addition, the responsibility in question also arises from the legislation relating to the reclamation activities. To that end, the parties bear the burden of responsibility, both personally and institutionally so that the parties can be subjected to administrative sanctions, civil sanctions, and criminal sanctions.
\end{abstract}

Keywords: Government Functions; Rights and Obligations; Contracts; Reclamation; Responsibilities.

\begin{abstract}
ABSTRAK
Penelitian ini bertujuan untuk menganalisis pengaturan penggunaan instrumen kontrak dalam pembangunan Centre Point of Indonesia (CPI) di Kota Makassar. Penelitian ini adalah penelitian normatif dengan menggunakan pendekatan perundang-undangan (statute approach) dan pendekatan konseptual (conceptual approach). Hasil penelitian menunjukkan bahwa pengaturan penggunaan instrumen kontrak dalam pembangunan Centre Point of Indonesia (CPI) di Kota Makassar dimungkinkan oleh peraturan perundang-undangan, yakni Undang-Undang Nomor 30 Tahun 2014 tentang Administrasi Pemerintahan, Undang-Undang Nomor 23 Tahun 2014 tentang Pemerintahan Daerah, dan Undang-Undang Nomor 27 Tahun 2007 jo. Undang-Undang Nomor 1 Tahun 2014 dan Pengelolaan Wilayah Pesisir dan Pulau-Pulau Kecil. Kontrak yang dimaksudkan dalam konteks ini adalah kontrak publik oleh karena salah satu pihaknya adalah Pemerintah Provinsi Sulawesi Selatan. Tanggung jawab para pihak dalam kontrak untuk pembangunan Centre Point of Indonesia (CPI) di Kota Makassar lahir dari adanya hak dan kewajiban masing-masing pihak yang diatur dalam Perjanjian. Selain itu, tanggung jawab yang dimaksud juga tibul dari peraturan perundang-undangan yang terkait dengan kegiatan reklamasi tersebut. Untuk itu, maka para pihak memikul beban tanggung jawab, baik secara personal maupun secara institusional sehingga para pihak dapat dinakan sanksi administratif, sanksi perdata, maupun sanksi pidana.
\end{abstract}

Keywords: Fungsi Pemerintahan; Hak dan Kewajiban; Kontrak; Reklamasi; Tanggung Jawab. 
Citation: Wahyu, Muhammad, Harustiati A. Moein, Mustafa Bola, and Muhammad Ilham Arisaputra. 2019. "Penggunaan Instrumen Kontrak Dalam Pembangunan Centre Point of Indonesia". Mulawarman Law Review 4 (2), 83-97. https://doi.org/10.30872/mulrev.v4i2.68.

\section{PENDAHULUAN}

Sumber daya alam sangat penting dalam kaitannya dengan kegiatan ekonomi dan kehidupan masyarakat manusia yang mengarah kepada kecenderungan pengurasan (depletion) dan degradasi (degradation). Sumber daya alam merupakan pendukung utama kehidupan manusia, maka konstitusi mengatur sedemikian rupa penguasaan sumber daya alam dalam rumusan Pasal 33 UUD NRI 1945 melalui konsep penguasaan negara. Negara dituntut memperluas tanggung jawabnya kepada rakyat. ${ }^{1}$ Berdasarkan Pasal 33 ini Negara memiliki kewajiban yang besar dalam mengurus sumber daya alam yang ada di wilayah NKRI untuk dimanfaatkan dan dikelola bagi sebesar-besarnya kemakmuran rakyat.

Dalam penyelenggaraan kesejahteraan rakyat dan pelayanan publik, maka pemerintah dapat melakukan kerjasama dengan pihak swasta yang merupakan bagian dari tindakan pemerintahan (bestuurhandelingen). Dengan adanya otonomi daerah, pemerintah daerah diberi kewenangan sendiri untuk mengurus dan mengelola asetaset yang dimilikinya demi terwujudnya fungsi otonomi daerah. Pengelolaan sumber daya alam harus dapat dilakukan dengan baik untuk memberikan manfaat kepada masyarakat. Namun, dengan adanya keterbatasan pemerintah (keterbatasan modal, teknologi, maupun sumber daya manusia), maka biasanya pengelolaan sumber daya alam kemudian dilakukan dengan dasar kerjasama dengan pihak ketiga.

Sumber daya alam yang banyak dikelola dan dimanfaatkan adalah sumber daya pesisir, antara lain dengan melakukan reklamasi pantai. Kewenangan pengelolaan wilayah pesisir sejak diberlakukannya Undang-undang Nomor 23 Tahun 2014 tentang Pemerintahan Daerah berada di tangan Pemerintah Pusat dan Pemerintah Provinsi. Pasal 14 ayat (1) Undang-Undang Nomor 23 Tahun 2014 tentang Pemerintahan Daerah mengatur bahwa "Penyelenggaraan Urusan Pemerintahan bidang kehutanan, kelautan, serta energi dan sumber daya mineral dibagi antara Pemerintah Pusat dan Daerah provinsi".

Hal ini memperlihatkan bahwa pemerintah kabupaten/kota tidak lagi memiliki kewenangan dalam mengelola wilayah laut dan pesisir. Kemudian Pasal 27 UndangUndang Nomor 23 Tahun 2014 memberikan kewenangan yang lebih banyak kepada pemerintah provinsi dalam hal pengelolaan wilayah laut dan pesisir. Pasal 27 mengatur sebagai berikut:

1. Daerah provinsi diberi kewenangan untuk mengelola sumber daya alam di laut yang ada di wilayahnya.

2. Kewenangan Daerah provinsi untuk mengelola sumber daya alam di laut sebagaimana dimaksud pada ayat (1) meliputi:

\footnotetext{
${ }^{1}$ Muhammad Ilham Arisaputra, Reforma Agraria Di Indonesia, Sinar Grafika, Jakarta,2015, Hal.
} 248-251. 
a. eksplorasi, eksploitasi, konservasi, dan pengelolaan kekayaan laut di luar minyak dan gas bumi;

b. pengaturan administratif;

c. pengaturan tata ruang;

d. ikut serta dalam memelihara keamanan di laut; dan

e. ikut serta dalam mempertahankan kedaulatan negara.

3. Kewenangan Daerah provinsi untuk mengelola sumber daya alam di laut sebagaimana dimaksud pada ayat (1) paling jauh 12 (dua belas) mil laut diukur dari garis pantai ke arah laut lepas dan/atau ke arah perairan kepulauan.

4. Apabila wilayah laut antardua Daerah provinsi kurang dari 24 (dua puluh empat) mil, kewenangan untuk mengelola sumber daya alam di laut dibagi sama jarak atau diukur sesuai dengan prinsip garis tengah dari wilayah antardua Daerah provinsi tersebut.

5. Ketentuan sebagaimana dimaksud pada ayat (3) dan ayat (4) tidak berlaku terhadap penangkapan ikan oleh nelayan kecil.

Pada Lampiran huruf Y tentang Pembagian Urusan Bidang Kelautan dan Perikanan, Sub Urusan angka 1 tentang Kelautan, Pesisir, dan Pulau-Pulau Kecil, kewenang pemerintah provinsi adalah sebagai berikut:

a. Pengelolaan ruang laut sampai dengan 12 mil di luar minyak dan gas bumi.

b. Penerbitan izin dan pemanfaatan ruang laut di bawah 12 mil di luar minyak dan gas bumi.

c. Pemberdayaan masyarakat pesisir dan pulau-pulau kecil.

Banyak proyek reklamasi pantai di Indonesia, ada yang memberikan manfaat lebih bagi masyarakat dan ada pula yang tidak memberikan manfaat kepada masyarakat. Contohnya proyek reklamasi di Kota Makassar dimana dibangun proyek Centre Point of Indonesia (CPI). Proyek ini dilaksanakan oleh Pemerintah Provinsi sesuai dengen kewenangannya dengan bekerja sama dengan pihak swasta, yakni PT Ciputra. Proyek tersebut sebenarnya sangat bagus karena dapat memberikan ikon baru bagi Kota Makassar dan Provinsi Sulawesi Selatan sebagai kota dunia. Namun, proyek tersebut mendapat tentangan dari masyarakat, khususnya masyarakat nelayan oleh karena dianggap proyek tersebut menghilangkan mata pencaharian mereka sebagai nelayan.

Pada Bulan Juni 2016, Wahana Lingkungan Hidup (Walhi) Makassar bersama dengan koalisi masyarakat sipil yang tergabung dalam "Aliansi Selamatkan Pesisir (ASP) Makassar" mengajukan gugatan ke Pengadilan Tata Usaha Negara dengan nomor perkara 11/6/2016/PTUN.MKS yang meminta pembatalan Surat Keputusan Gubernur Sulawesi Selatan Nomor 664/2013 terkait pemberian izin reklamasi kawasan CPI kepada PT Yasmin Bumi Asri dan Ciputra grup. Reklamasi dipandang telah menyalahi ketentuan dalam UU No 32 Tahun 2009 tentang Lingkungan Hidup, PP No 27 Tahun 2012 tentang Izin Lingkungan, Perpres No 122 Tahun 2012 tentang Reklamasi di Wilayah pesisir dan Pulau-Pulau Kecil, serta Permen Kelautan dan Perikanan No 17 tahun 2013 tentang Pedoman Perizinan Reklamasi. Gugatan ini didukung hasil kajian ASP bahwa $60 \%$ terumbu karang di wilayah pesisir kota makassar telah rusak. Alokasi ruang reklamasi yang nantinya akan dilaksanakan dalam sebuah proyek besar 
reklamasi akan menambah parah kerusakan terumbu karang. ${ }^{2}$ Selain itu, reklamasi juga semakin memperparah pencemaran air laut di sekitar pantai Losari, Makassar. Namun demikian, gugatan yang dilakukan oleh Walhi Makassar dan ASP ditolak oleh majelis hakim PTUN dengan pertimbangan bahwa tidak ada kepentingan publik yang dirugikan dalam objek sengketa. ${ }^{3}$

Dalam pelaksanaan proyek CPI ini, Pemerintah Provinsi Sulawesi Selatan bekerjasama dengan PT Yasmin Bumi Asri dan Ciputra Grup sebagai investor. Kerjasama tersebut dituangkan dalam bentuk kontrak, yakni Perjanjian Kerja Sama Nomor 252/VII/PEMPROV/2013 dan Nomor 231/YBA/VII/2013 antara Pemerintah Provinsi Sulawesi Selatan dengan PT. Yasmin Bumi Asri tentang Reklamasi Kawasan Centre Point of Indonesia Di Makassar. ${ }^{4}$

Pemerintah Provinsi Sulawesi Selatan melakukan kontrak kerjasama dengan pihak investor oleh karena proyek pembangunan CPI tersebut tidak dianggarkan dalam APBD Provinsi Sulawesi Selatan. Berdasarkan Perjanjian Kerja Sama (PKS) antara Pemerintah Provinsi (Pemprov) Sulawesi Selatan dan PT Yasmin Bumi Asri, sekitar 50 hektar lahan reklamasi tersebut akan diserahkan kepada Pemprov Sulsel dari total keseluruhan pengembangan kawasan CPI seluas 157 hektar. Berdasarkan pemaparan latar belakang tersebut, artikel ini akan mengkaji mengenai penggunaan instrumen kontrak dalam pembangunan Centre Point of Indonesia (CPI) di Kota Makassar.

\section{METODE PENELITIAN}

Penelitian ini adalah penelitian hukum normatif (normative legal research). Pendekatan yang digunakan dalam penelitian ini menggunakan pendekatan perundang-undangan (statute approach) dan pendekatan konseptual (conceptual approach). Pendekatan undang-undang (statute approach) dilakukan dengan menelaah semua undang-undang dan regulasi yang bersangkut paut dengan isu hukum yang sedang ditangani. ${ }^{5}$ Pendekatan konseptual (conceptual approach) adalah pendekatan yang beranjak dari pandangan-pandangan dan doktrin-doktrin yang berkembang di dalam ilmu hukum. Pemahaman akan pandangan-pandangan dan doktrin-doktrin tersebut merupakan sandaran bagi peneliti dalam membangun suatu argumentasi hukum dalam memecahkan isu yang dihadapi. ${ }^{6}$

Penelitian ini akan dilakukan di Propinsi Sulawesi Selatan, yakni di Kota Makassar oleh karena Kota Makassar merupakan lokasi proyek pembangunan Centre Point of

${ }^{2}$ Zulkifli Aspan, Ariani Arifin, Anshori llyas, Ahsan Yunus (2019). Perizinan Pengelolaan Wilayah Pesisir sebagai Kewenangan yang Diderivasi dari Hak Menguasai Negara, Al-Azhar Islamic Law Review Vol. 1 (1), 9-25

3 Sumber: http://makassar.tribunnews.com/2016/07/28/breaking-news-hakim-ptun-makassartolak-gugatan-walhi-atas-reklamasi-cpi, diakses tanggal 6 Janiari 2018. Lihat pula Eksaminasi Publik Wahana Lingkungan Hidup (Walhi) Makassar terhadap Putusan Pengadilan Tata Usaha Negara (PTUN) Makassar Nomor: 11/G/LH/2016/PTUN.Mks atas Gugatan Walhi Sulsel terhadap Surat Izin Gubernur Sulawesi Selatan terkait Reklamasi Center Point of Indonesia (CPI), sumber: https://walhi.or.id/anotasieksaminasi-putusan-ptun-makassar-kasus-reklamasi-cpi/, diakses tanggal tanggal 6 Janiari 2018.

${ }^{4}$ Hasil Pra Penelitian yang dilakukan penulis di Biro Hukum Sekretariat Provinsi Sulawesi Selatan

${ }^{5}$ Peter Mahmud Marzuki, Penelitian Hukum, Kencana, Jakarta, 2005, hal. 93.

${ }^{6}$ Ibid, hal. 95 
Indonesia (CPI). Secara spesifik, penelitian akan dilaksanakan di Sekretariat Daerah Provinsi Sulawesi Selatan, DPRD Sulawesi Selatas, Dinas Kelautan dan Perikanan Provinsi Sulawesi Selatan, dan Dinas Penanaman Modal dan Pelayanan Terpadu Satu Pintu Provinsi Sulawesi Selatan.

\section{Implementasi Peraturan Hukum Pada Kontrak Pembangunan Centre Point of Indonesia}

Pasal 2 ayat (2) UUPA dikemukakan bahwa hak menguasai negara adalah memberikan kewenangan kepada negara untuk mengatur dan menyelenggarakan peruntukan, penggunaan, persediaan dan pemeliharaan bumi, air, dan ruang angkasa. Hak menguasai negara bukanlah berarti negara yang memiliki tanah, tetapi memberikan kewenangan kepada negara sebagai organisasi kekuasaan dari bangsa Indonesia pada tingkatan tertinggi untuk mengatur dan menyelenggarakan peruntukan, penggunaan, persediaan dan pemeliharaan bumi, air, dan ruang angkasa. Selain itu, negara juga memiliki kewenangan untuk menentukan dan mengatur hak-hak yang dapat dipunyai atas bumi, air, dan ruang angkasa serta menentukan dan mengatur hubunganhubungan hukum antar orang-orang dan perbuatan-perbuatan hukum mengenai bumi, air dan ruang angkasa dengan tujuan untuk mencapai sebesar-besarnya kemakmuran rakyat dalam rangka mewujudkan masyarakat yang adil dan makmur.

Hak Menguasai Negara sebagaimana Pasal 2 UUPA bersumber dari Pasal 33 ayat (3) UUD NRI 1945 dimana terkandung makna di dalamnya bahwa Negara memiliki kewajiban yang besar dalam mengurus sumber daya alam yang ada di wilayah NKRI untuk dimanfaatkan dan dikelola bagi sebesar-besarnya kemakmuran rakyat. Pemanfaatan dan pengelolaan ini diimplementasikan dalam bentuk pelayanan publik dalam rangka penyelenggaraan kesejahteraan rakyat. ${ }^{7}$

Desentralisasi dan otonomi daerah sebagai kebijakan pemerintah menjadi penting ketika dikaitkan dengan pengelolaan sumber daya alam. Pengelolaan sumber daya alam sebagai unsur lingkungan dengan berbagai keterbatasannya dalam hal regenerasi dan asimilasi memerlukan perhatian yang lebih dari level pemerintahan yang ada. Pembangunan berkelanjutan sebagai cita-cita penyelenggaraan pemerintahan perlu untuk memperhatikan daya dukung lingkungan melalui pengelolaan sumber daya alam yang berkelanjutan. Peran pemerintah propinsi sebagai pihak yang mengkoordinasikan penyelenggaraan pemerintahan antar kabupaten/kota di wilayahnya menjadi sangat strategis. Posisi sumber daya alam yang tidak dapat dipisahkan oleh batas-batas administratif menjadi tantangan yang perlu untuk dipertimbangkan dalam mengelola sumber daya alam.

Tidak nyatanya peran pemerintah provinsi dalam hal kewenangan menyebabkan beberapa perubahan terjadi dalam sistem pemerintahan daerah di Indonesia. Pada Tahun 2014, Undang-Undang Nomor 32 Tahun 2004 tentang Pemerintahan Daerah kemudian direvisi dan digantikan dengan Undang-Undang Nomor 23 Tahun 2014

7 Slamet Suhartono, Desentralisasi Pengelolaan Sumber Daya Alam Untuk Mewujudkan Kesejahteraan Masyarakat, DiH Jurnal Ilmu Hukum Volume 9 Nomor 18, Fakultas Hukum Universitas 17 Agustus, Jakarta, 2013, hal. 114 
tentang Pemerintahan Daerah. ${ }^{8}$ Undang-Undang Nomor 23 Tahun 2014 ini memberikan penguatan terhadap eksistensi Pemerintah Provinsi dalam pelaksanaan sistem pemerintahan di Indonesia. Dalam hal pemanfaatan dan pengelolaan sumber daya alam, Undang-Undang Nomor 23 Tahun 2014 ini tidak lagi hanya memberikan kewenangan kepada pemerintah kabupaten/kota, namun ada beberapa kewenangan pemanfaatan dan pengelolaan sumber daya alam yang diberikan kepada pemerintah provinsi, tidak terkecuali pemanfaatan dan pengelolaan wilayah pesisir.

Kewenangan pemerihntah provinsi dalam pengelolaan wilayah pesisir dan pulau-pulau kecil merupakan kewenangan yang bersifat atributif oleh sebab bersumber dari Undang-Undang Nomor 23 Tahun 2014 tentang Pemerintahan Daerah. Sebagaimana teori kewenangan menyebutkan bahwa sumber kewenangan ada 3, yakni atribusi, delegasi, dan mandat. Kewenangan Atribusi lazimnnya berasal dari adanya pembagian kekuasaan negara oleh UUD. Istilah lain untuk kewenangan atributif adalah kewenangan asli atau kewenangan yang tidak dibagi-bagikan kepada siapa pun. Dalam kewenangan atributif pelaksanaannya dilakukan sendiri oleh pejabat atau badan tersebut tertera dalam peraturan dasarnya. ${ }^{9}$

Penggunaan instrumen kontrak dalam tindakan pemerintahan tetap dimungkinkan oleh peraturan perundang-undangan. Misalnya dalam Pasal 1 angka 20 UndangUndang Nomor 30 Tahun 2014 tentang Administrasi Pemerintahan (disingkat UU Administrasi Pemerintahan) dijelaskan pengertian konsesi sebagai keputusan pejabat pemerintahan yang berwenang sebagai wujud persetujuan dari kesepakatan badan dan/atau pejabat pemerintahan dengan selain badan dan/atau pejabat pemerintahan dalam pengelolaan fasilitas umum dan/atau sumber daya alam dan pengelolaan lainnya sesuai dengan ketentuan peraturan perundang-undangan. Ketentuan Pasal 1 angka 20 UU Administrasi Pemerintahan memperlihatkan bahwa pemerintah dapat bekerjasama dengan pihak lain dengan menggunakan instrumen kontrak.

Khusus dalam pengelolaan wilayah pesisir dan pulau-pulau kecil, Undang-Undang Nomor 27 Tahun 2007 jo. Undang-Undang Nomor 1 Tahun 2014 juga dapat dikerjasamakan dengan pihak lain oleh sebab salah satu asas dalam undang-undang tersbut adalah asas kemitraan yang diartikan sebagai kesepakatan kerja sama antar pihak yang berkepentingan berkaitan dengan Pengelolaan Wilayah Pesisir dan PulauPulau Kecil. ${ }^{10}$

Secara umum, tindakan pemerintahan adalah tindakan atau perbuatan yang dilakukan oleh administrasi negara dalam melaksanakan tugas pemerintahan. Kontjoro Purbopranoto menyatakan bahwa tindakan pemerintahan adalah segala tindakan dan

8 Undang-Undang Nomor 23 Tahun 2014 tentang Pemerintahan Daerah ini telah mengalami beberapa kali perubahan, yakni Undang-Undang Nomor 2 Tahun 2015 tentang Perubahan Atas UndangUndang Nomor 23 Tahun 2014 tentang Pemerintahan Daerah, dan terakhir diubah dengan UndangUndang Nomor 9 Tahun 2015 tentang Perubahan Kedua Atas Undang-Undang Nomor 23 Tahun 2014 tentang Pemerintahan Daerah

${ }^{9}$ Lutfi Effendi, Pokok-Pokok Hukum Administrasi, Bayumedia Publishing, Malang, 2004, hal. 7779.

10 Lihat penjelasan Pasal 3 Huruf e Undang-Undang Nomor 27 Tahun 2007 jo. Undang-Undang Nomor 1 Tahun 2014 
kewenangan alat-alat pemerintahan untuk menjalankan tugas/tujuan dengan menggunakan wewenang khusus/tertentu. Romeyn sebagaimana dikutip oleh Kontjoro Purbopranoto meyatakan bahwa "tindak pangreh (bestuurshandeling) adalah tiap-tiap tindakan/perbuatan dari pada satu alat perlengkapan pemerintahan (bestuursorgaan), juga diluar lapangan hukum Tata Pemerintahan, misalnya keamanan, peradilan, dan lain-lain, yang bermaksud untuk menimbulkan akibat hukum dibidang hukum adminsitrasi.

Dalam kontrak pengelolaan sumber daya alam, kontrak keperdataan akan mendegradasi kedaulatan Negara atas sumber daya alam dan segala aset yang dimiliknya. Hubungan antara Negara dan sumber daya alam serta aset-aset yang dimilikinya sepanjang dikonstruksi dalam bentuk kontrak yang melibatkan Pemerintah sebagai salah satu pihak akan bertentangan dengan prinsip penguasaan negara yang dimaksud oleh konstitusi. Negara tidak dapat disederajatkan dengan badan hukum atau badan usaha karena akan melemahkan posisi Negara sebagai organisasi kekuasaan tertinggi. Hal ini sebagaimana ditegaskan dalam Putusan Mahkamah Konstitusi Nomor 36/PUU-X/2012. ${ }^{11}$

Penjelasan di atas dapat dikonseptualisasikan dalam bidang pengelolaan sumber daya peisir mengingat salah satu sumber daya alam adalah wilayah pesisir dan laut beserta isinya. Pengelolaan wilayah pesisir dan pulau-pulau kecil yang terjadi di Provinsi Sulawesi Selatan adalah dalam rangka pembangunan Centre Point of Indonesia dimana Pemerintah Provinsi Sulawesi Selatan bekerjasama dengan PT. Yasmin Bumi Asri yang dituangkan dalam bentuk kontrak. Dari hasil penelusuran penulis di Sekretariat Daerah Provinsi Sulawesi Selatan ditemukan bahwa antara Pemeritah Provinsi Sulawesi Selatan dengan PT. Yasmin Bumi Asri menuangkan kesepakatan kerjasamanya dalam bentuk Perjanjian Kerjasama Nomor 252/VII/PEMPROV/2013 dan Nomor 231/YBA/VII/2013 tentang Reklamasi Kawasan Centre Point of Indonesia Di Makassar tertanggal 29 Juli 2013.

Perjanjian Kerja Sama tentang Reklamasi Kawasan Centre Point of Indonesia Di Makassar tersebut disusun berlandaskan pada beberapa peraturan perundangundangan sebagaimana dituangkan dalam Pasal 1 perjanjian kerja sama tersebut, yakni:

1. Undang-Undang Nomor 26 Tahun 2007 tentang Penataan Ruang

2. Peraturan Pemerintah Nomor 15 Tahun 2010 tentang Penyelenggaraan Penataan Ruang

3. Peraturan Presiden Nomor 55 Tahun 2011 tentang Rencana Tata Ruang Kawasan Perkotaan Makassar, Maros, Sungguminasa dan Takalar

4. Peraturan Presiden Nomor 122 Tahun 2012 tentang Reklamasi di Wilayah Pesisir dan Pulau-Pulau Kecil

5. Peraturan Menteri Dalam Negeri Nomor 1 Tahun 2008 tentang Pedoman Perencanaan Kawasan Perkotaan

11 Lihat Putusan Mahkamah Konstitusi Nomor 36/PUU-X/2012 tentang Pengujian UndangUndang Nomor 22 Tahun 2001 tentang Minyak dan Gas Bumi Terhadap Undang-Undang Dasar Negara Republik Indonesia Tahun 1945, hal. 108. Dikutip dalam Anshori Ilyas, et.al. 2017. Kontrak Publik. UPT Unhas Press. Makassar. hal. 106. 
6. Peraturan Daerah Provinsi Sulawesi Selatan Nomor 9 Tahun 2009 tentang Rencana Tata Ruang Wilayah Provinsi Sulawesi Selatan

7. Peraturan Daerah Kota Makassar Nomor 6 Tahun 2006 tentang Rencana Tata Ruang Wilayah Kota Makassar yang kemudian diubah menjadi Peraturan Daerah Nomor 4 Tahun 2015 tentang Rencana Tata Ruang Wilayah Kota Makassar 2015-2034.

8. Keputusan Gubernur Sulawesi Selatan Nomor 2026/IV/Tahun 2011 tentang Penetapan Kawasan Centrepoint of Indonesia

9. Keputusan Gubernur Sulawesi Selatan Nomor 704/II/Tahun 2012 tentang Penetapan Lokasi Centrepoint of Indonesia

10. Keputusan Walikota Makassar Nomor 604/175/Kep/II/09 tentang Penetapan Lokasi Pemerintah Provinsi Sulawesi Selatan Untuk Kawasan Pembangunan Centre Point of Indonesia Sebelah Barat Pantai Losari Di Kecamatan Tamalate dan Kecamatan Mariso Kota Makassar.

Di samping peraturan perundang-undangan sebagaimana disebutkan di atas, perjanjian kerja sama tersebut secara tidak tertulis juga tunduk pada peraturan perundang-undangan lainya yang terkait, yakni sebagai berikut:

1. Undang-Undang Nomor 27 Tahun 2007 tentang Pengelolaan Wilayah Pesisir dan Pulau-Pulau Kecil sebagaimana telah diubah dengan Undang-Undang Nomor 1 Tahun 2014 tentang Perubahan Atas Undang-Undang Nomor 27 Tahun 2007 tentang Pengelolaan Wilayah Pesisir dan Pulau-Pulau Kecil.

2. Undang-Undang Nomor 32 Tahun 2009 tentang Perlindungan dan Pengelolaan Lingkungan Hidup.

3. Undang-Undang Nomor 23 Tahun 2014 tentang Pemerintahan Daerah.

4. Undang-Undang Nomor 30 Tahun 2014 tentang Administrasi Pemerintahan.

5. Peraturan Daerah Provinsi Sulawesi Selatan Nomor 6 Tahun 2007 tentang Pengelolaan Wilayah Pesisir.

Undang-Undang Nomor 27 Tahun 2007 jo. Undang-Undang Nomor 1 Tahun 2014 serta Undang-Undang Nomor 23 Tahun 2014 mengatur mengenai kewenagan pemerintah provinsi dalam mengelola kawasan laut dan wilayah pesisir, yakni sejauh 12 mil laut. Hal ini diimplementasikan dalam ketentuan Pasal 3 Perjanjian Kerja Sama tentang Reklamasi Kawasan Centre Point of Indonesia dimana ditentukan bahwa objek dan ruang lingkup pekerjaan berada pada batas wilayah kewenangan Pemerintah Provinsi Sulawesi Selatan.

Kemudian Undang-Undang Nomor 30 Tahun 2014 menjadi landasan penggunaan instrumen kontrak sebagai instrumen hukum pemerintahan. Sedangkan Perda Sulsel Nomor 6 Tahun 2007 sebagai dasar pengelolaan wilayah pesisir oleh pemerintah Provinsi Sulawesi Selatan. Pelaksanaan reklamasi harus didasarkan pada Rencana Tata Ruang Wilayah (RTRW), baik RTRW Provinsi maupun RTRW Kabupaten/Kota. Hal ini diatur dalam Pasal 4 ayat (1) Peraturan Pemerintah Nomor 122 Tahun 2012 yang menentukan bahwa penentuan lokasi reklamasi didasarkan pada Rencana Zonasi Wilayah Pesisir dan Pulau-Pulau Kecil (RZWP-3-K) dan atau Rencana Tata Ruang Wilayah, baik nasional, provinsi, maupun kabupaten/kota. Ketentuan ini diimplementasikan dalam ketentuan Pasal 5 dalam perjanjian kerjasama tersebut 
mengenai kewajiban Pemerintah Provinsi Sulawesi Selatan sebagai Pihak Kesatu dimana lokasi reklamasi disiapkan oleh Pemerintah Provinsi Sulawesi Selatan sesuai dengan master plan.

Atas dasar berbagai peraturan perundang-undangan sebagaimana disebutkan di atas, maka kegiatan reklamasi pantai dalam rangka pembangunan Centre Point of Indonesia kemudian dituangkan ke dalam kontrak kerjasama antara pemerintah dengan pengembang. Kebebasan para pihak untuk menentukan klausul perjanjian dibatasi oleh peraturan perundang-undangan yang mengatur mengenai administrasi pemerintahan oleh sebab salah satu pihak dalam perjanjian/kontrak tersebut adalah Pemerintah Daerah Provinsi Sulawesi Selatan dimana pemerintah dalam melakukan tindakan hukum diatur dalam peraturan perundang-undangan, misalnya UndangUndang Nomor 30 Tahun 2014 tentang Administrasi Pemerintahan. Dengan demikian, isi dari Perjanjian Kerja Sama tentang Reklamasi Kawasan Centre Point of Indonesia Di Makassar tidak mengatur banyak hal di dalamnya karena sudah diatur dalam peraturan perundang-undangan. Hal yang cukup penting yang diatur dalam perjanjian kerja sama tersebut adalah mengenai hak dan kewajiban, lingkup pekerjaan (termasuk jangka waktunya), pengawasan, dan hasil pekerjaan. Klausul-klausul dalam perjanjian mengikat para pihak sebagaimana Asas Pacta Sunt Servanda sehingga apabila terjadi pelanggaran terhadap perjanjian/kontrak tersebut, maka pihak yang melanggar dapat digugat di pengadilan.

Pengujian keabsahan perjanjian kerjasama tentang reklamasi Kawasan Centre Point of Indonesia dapat dianalisis dengan memperhatikan ketentuan Pasal 1320 BW yang mengatur tentang syarat sah perjanjian, yakni sebagai berikut:

\section{Sepakat Para Pihak}

Dengan adanya kata sepakat untuk mengadakan perjanjian, maka berarti para pihak haruslah mempunyai kebebasan kehendak. ${ }^{12}$ Para pihak tidak mendapat sesuatu tekanan yang mengakibatkan adanya "cacat" bagi perwujudan kehendak tersebut. Sepakat dimaksudkan bahwa kedua subjek yang mengadakan perjanjian itu harus bersepakat, setuju, atau seia-sekata mengenai hal-hal yang pokok dari perjanjian yang diadakan itu $^{13}$. Sepakat merupakan syarat subjektif pertama terbentuknya perjanjian yang sah di antara para pihak.

Kesepakatan dalam perjanjian merupakan perwujudan dari kehendak 2 (dua) atau lebih pihak dalam perjanjian mengenai apa yang mereka kehendaki untuk dilaksanakan, bagaimana cara melaksanakannya, kapan harus dilaksanakan, dan siapa yang harus melaksanakan. ${ }^{14}$ Pada dasarnya sebelum para pihak sampai pada kesepakatan mengenai hal-hal tersebut, maka salah satu atau lebih pihak dalam perjanjian tersebut akan menyampaikan terlebih dahulu suatu bentuk pernyataan yang biasa disebut penawaran (offer), diikuti penerimaan penawaran (acceptance) dari pihak lainnya, yaitu mengenai apa yang dikehendaki oleh pihak tersebut dengan segala

\footnotetext{
12 Mariam Darus Badrulzaman, Aneka Hukum Bisnis, Alumni, Bandung, 1994, hal. 24.

13 Subekti, Op.Cit., hal. 17.

14 Kartini Muljadi dan Gunawan Widjaja, Perikatan Yang Lahir Dari Perjanjia, PT. RajaGrafindo Persada, Jakarta, 2008, hal. 95.
} 
macam persyaratan yang mungkin dan diperkenankan oleh hukum untuk disepakati oleh para pihak. Konsekuensi hukumnya adalah bahwa jika syarat kesepakatan kehendak ini tidak terpenuhi dalam perjanjian tersebut akan mengakibatkan kontrak tersebut "dapat dibatalkan".

Dalam Pasal 1321 KUHPerdata dijelaskan bahwa "Tiada sepakat yang sah apabila sepakat itu diberikan karena kekhilafan, atau diperolehnya dengan paksaan atau penipuan". Perjanjian Kerjasama antara Pemerintah Provinsi Sulawesi Selatan dengan PT. Yasmin Bumi Asri tentang Revitalisasi Kawasan Centre Point of Indonesia Di Makassar ditandatangani oleh semua pihak. Pembubuhan tanda tangan dalam perjanjian merupakan wujud dari sepakatnya para pihak atas apa yang telah diperjanjikan.

\section{Kecakapan dan/atau kewenangan bertindak}

Orang yang membuat suatu perjanjian harus cakap menurut hukum. Pada asasnya, setiap orang yang sudah dewasa menurut hukum dan sehat pikirannya adalah cakap menurut hukum. ${ }^{15}$ Adanya kecakapan untuk bertindak dalam hukum merupakan syarat subjektif kedua untuk terbentuknya suatu perjanjian yang sah di antara para pihak. Jika syarat ini tidak terpenuhi, maka perjanjian itu dinyatakan "dapat dibatalkan". Dalam Pasal 1329 BW dijelaskan bahwa "Setiap orang adalah cakap untuk membuat perikatan-perikatan jika ia oleh undang-undang tidak dinyatakan cakap". Tak cakap untuk membuat suatu perjanjian adalah ${ }^{16}$ :

a. Orang-orang yang belum dewasa;

b. Mereka yang di taruh di bawah pengampunan;

c. Orang-orang perempuan, dalam hal-hal yang ditetapkan oleh undang-undang, dan pada umumnya semua orang kepada siapa undang-undang telah melarang membuat perjanjian tertentu.

Kecakapan bertindak dalam banyak hal berhubungan dengan masalah kewenangan bertindak dalam hukum. Meskipun kedua hal tersebut secara prinsipil berbeda, namun dalam membahas masalah kecakapan bertindak yang melahirkan suatu perjanjian yang sah, maka masalah kewenangan untuk bertindak juga tidak dapat dilupakan. Jika masalah kecakapan untuk bertindak berkaitan dengan masalah kedewasaan dari orang perorangan yang melakukan suatu tindakan atau perbuatan hukum, maka masalah kewenangan berkaitan dengan kapasitas orang perorangan tersebut yang bertindak atau berbuat dalam hukum. Dapat saja orang yang cakap bertindak dalam hukum tetapi ternyata tidak berwenang untuk melakukan suatu perbuatan hukum, dan sebaliknya seorang yang dianggap berwenang untuk bertindak melakukan suatu perbuatan hukum, ternyata karena suatu hal menjadi tidak cakap untuk bertindak dalam hukum. ${ }^{17}$

Dalam perjanjian Kerjasama tentang Reklamasi Kawasan Centre Point of Indonesia Di Makassar, Pihak Pertama yakni Pemerintah Provinsi Sulawesi Selatan diwakili oleh Dr. H. Syahrul Yasin Limpo, S.H., M.H., M.Si. sebagai Gubernur Sulawesi Selatan.

\footnotetext{
15 Subekti. 1996. Hukum Perjanjian. PT. Intermasa. Jakarta, hal. 17.

${ }^{16}$ Lihat Pasal $1330 \mathrm{BW}$

${ }^{17}$ Kartini Muljadi dan Gunawan Widjaja, Op.Cit., hal. 127
} 
Sedangkan Pihak Kedua yakni PT. Yasmin Bumi Asri diwakili oleh Dr. Adityawarman M. Kouwagam, S.H., M.Kn. selaku Direktur Utama. Para pihak dianggap telah cakap menurut aturan hukum Indonesia, baik H. Syahrul Yasin Limpo selaku Gubernur Sulawesi Selatan yang bertindak untuk dan atas nama Pemerintah Provinsi Sulawesi Selatan maupun Adityawarman M. Kouwagam selaku Direktur Utama PT. Yasmin Bumi Asri yang bertindak untuk dan atas nama PT. Yasmin Bumi Asri menurut aturan hukum yang berlaku adalah cakap untuk melakukan suatu perjanjian.

\section{Suatu hal tertentu}

Suatu perihal tertentu adalah perihal yang merupakan objek dari suatu kontrak. Jadi suatu kontrak haruslah mempunyai objek tertentu. Suatu perjanjian harus mengenai suatu hal tertentu, artinya apa yang diperjanjikan, hak-hak dan kewajiban kedua belah pihak jika timbul suatu perselisihan. Barang yang dimaksudkan dalam perjanjian paling sedikit harus ditentukan jenisnya ${ }^{18}$. Suatu hal tertentu merupakan syarat objektif pertama dalam suatu perjanjian dan jika syarat ini tidak terpenuhi maka suatu perjanjian "batal demi hukum".

Secara sepintas, dengan rumusan "Suatu perjanjian harus mempunyai sebagai pokok suatu barang yang paling sedikit ditentukan jenisnya", tampaknya KUHPerdata hanya menekankan pada perikatan untuk memberikan atau menyerahkan sesuatu. Namun demikian, jika diperhatikan lebih lanjut, rumusan tersebut hendak menegaskan bahwa apapun jenis perikatan untuk memberikan sesuatu, berbuat sesuatu, atau tidak berbuat sesuatu, KUHPerdata hendak menjelaskan bahwa semua jenis perikatan tersebut pasti melibatkan keberadaan atau eksistensi dari suatu kebendaan yang tertentu. ${ }^{19}$

Dalam Perjanjian Kerjasama tentang Reklamasi Kawasan Centre Point of Indonesia Di Makassar, objek perjanjian sudah nampak pada judul perjanjian kerjasama, yakni reklamasi kawasan Centre Point of Indonesia Di Makassar. Selain itu, Pasal 3 Perjanjian Kerjasama ini juga menegaskan objek dan ruang lingkup pekerjaan, yakni:

1. Objek pekerjaan adalah reklamasi berupa penimbunan dan pengurungan serta pembangunan talud pada kawasan Centre Point of Indonesia meliputi areal seluas $\pm 157,23 \mathrm{Ha}$.

2. Lingkup pekerjaan sebagaimana dimaksud pada ayat (1) adalah penimbunan dan pengurungan serta pembangunan talud pada areal 157,23 Ha sesuai dengan Master Plan dan Rencana Teknis terlampir.

Ketentuan lainnya yang menegaskan objek perjanjian adalah ketentuan Pasal 6 dalam perjanjian tersebut yang mengatur mengenai pelaksanaan pekerjaan. Dengan demikia, maka Perjanjian Kerjasama antara Pemerintah Provinsi Sulawesi Selatan dengan PT. Yasmin Bumi Asri tentang Reklamasi Kawasan Centre Point of Indonesia Di Makassar adalah sah karena memenuhi syarat ketiga untuk sahnya suatu perjanjian, yaitu terpenuhinya syarat "suatu hal tertentu".

\footnotetext{
${ }^{18}$ R. Subekti, Op.Cit., hal. 19.

19 Kartini Muljadi dan Gunawan Widjaja, Op.Cit., hal. 155
} 


\section{Suatu sebab yang legal}

Sebab yang legal (Oorzaak) atau causa dalam Bahasa Latin dimaksudkan bahwa sebab itu adalah sesuatu yang menyebabkan seseorang membuat perjanjian yang termaksud dan harus dihilangkan suatu kemungkinan salah sangka ${ }^{20}$. Syarat keempat ini adalah syarat objektif kedua dalam suatu perjanjian yang apabila syarat ini tidak terpenuhi dalam suatu perjanjian, maka perjanjian itu dinyatakan "batal demi hukum".

Dalam Pasal 1335 BW dijelaskan bahwa "Suatu perjanjian tanpa sebab, atau yang telah dibuat karena sesuatu sebab yang palsu atau terlarang, tidak mempunyai kekuatan". Kemudian Pasal 1336 W menetukan bahwa "Jika tidak dinyatakan suatu sebab, tetapi ada suatu sebab yang halal, ataupun jika ada suatu sebab lain, daripada yang dinyatakan, perjanjiannya namun demikian adalah sah". Sedangkan Pasal 1337 BW menetukan bahwa "Suatu sebab adalah terlarang, apabila dilarang oleh undangundang, atau apabila berlawanan dengan kesusilaan baik atau ketertiban umum".

Undang-undang hanya melihat pada apa yang tercantum dalam perjanjian, apa yang merupakan prestasi yang harus dilakukan oleh para pihak yang merupakan prestasi pokok, yang merupakan unsur essensialia atau yang terkait erat dengan unsur essensialia dalam perjanjian tersebut, tidak mungkin perjanjian tersebut akan dibuat oleh para pihak. Tidak mungkin ada persetujuan yang tidak mempunyai causa karena causa merupakan isi dari persetujuan, dan tiap-tiap persetujuan tentu mempunyai isi, bagaimanapun sedikit atau kecilnya. Suatu perjanjian bukanlah suatu tempat yang diisi, melainkan berupa isi itu sendiri. ${ }^{21}$

Dalam Pasal 2 Perjanjian Kerjasama tentang Reklamasi Kawasan Centre Point of Indonesia Di Makassar disebutkan bahwa kerja sama para pihak diaksanakan dengan prinsip itikad baik, saling menguntungkan, keadilan, dan akuntabel. Prinsip ini setidaknya mampu memperlihatkan bahwa kerja sama antara Pemerintah Provinsi Sulawesi Selatan dengan PT. Yasmin Bumi Asri adalah kegiatan untuk kepentingan umum. Di samping itu, kegiatan yang dimaksudkan dalam perjanjian tersebut adalah kegiatan yang pada prinsipnya tidak bertentangan dengan ketentuan peraturan perundang-undangan, yakni Undang-Undang Nomor 23 Tahun 2014 tentang Pemerintahan Daerah dan Undang-Undang Nomor 27 Tahun 2007 tentang Pengelolaan Wilayah Pesisir dan Pulau-Pulau Kecil sebagaimana telah direvisi menjadi Undang-Undang Nomor 1 Tahun 2014 tentang Perubahan Atas Undang-Undang Nomor 27 Tahun 2007 tentang Pengelolaan Wilayah Pesisir dan Pulau-Pulau Kecil.

Menurut Since Erna Lamba22 bahwa penunjukan PT. Yasin Bumi Asri dilakukan sesuai ketentuan pengadaan barang dan jasa pemerintah, yakni dimulai dari tender/lelang yang dilaksanakan pada Tanggal 28 Mei 2013 dengan tahapan proses sebagai berikut:

a. Pengumuman pascakualifikasi melalui website http://lpse.sulselprov.go.id

b. Pendaftaran dan pengambilan dokumen pengadaan.

c. Pemberian penjelasan (Aanwijzing).

${ }^{20}$ Subekti, Op.Cit., hal. 19.

${ }^{21}$ Wirjono Prodjodikoro. 2004. Asas-asas Hukum Perjanjian. Bandar Maju. Bandung.hal. 37.

22 Dr. Since Erna Lamba, S.P., M.P., Kepala Biro Perekonomian Sekretariat Daerah Provinsi Sulawesi Selatan, wawancara tanggal 13 Agustus 2018. 
d. Penyampaian/pemasukan dokumen penawaran.

e. Evaluasi dokumen penawaran.

f. Evaluasi isian dokumen kualifikasi.

g. Pembuktian kualifikasi dan pembuatan Berita Acara Pembuktian Kualifikasi.

Berdasarkan evaluasi dokumen penawaran yang berpedoman pada dokumen pelalangan, maka diperoleh 5 (lima) investor penawaran tertinggi lahan tereklamasi yang diperuntukkan bagi Pemerintah Provinsi Sulawesi Selatan, yakni PT. Yasmin Bumi Asri seluas 50,47 Ha; PT. Haka Utama seluas 49,20 Ha; PT. Rama Sarana Persada seluas 48,70 Ha; PT. Harfia Graha Perkasa seluas 48,17 Ha; PT. Ikram Tiga Berlian seluas 47,34 Ha.

Pemenang lelang kemudian ditetapkan pada tanggal 8 Juli 2013 berdasarkan Berita Acara Hasil Pelelangan (BAHP) Nomor 08/PLI/Pemprov.Sulsel/VI/2013 oleh Panitia Lelang Proyek Investasi Reklamasi Centre Point of Indonesia. PT Yasmin Bumi Asri kemudian ditetapkan sebagai pemenang karena mengajukan penawaran tertinggi lahan tereklamasi untuk Pemerintah Provinsi Sulawesi Selatan, yakni seluas 50,47 Hektar. ${ }^{23}$

Pada prosesnya kemudian, PT. Yasmin Bumi Asri kemudian ditetapkan sebagai pelaksana proyek yang dimana kerjasama antara PT. Yasmin Bumi Asri dan Pemerintah Provinsi Sulawesi Selatan menuangkannya dalam bentuk Perjanjian Kerjasama Nomor 252/VII/PEMPROV/2013 dan Nomor 231/YBA/VII/2013 tentang Reklamasi Kawasan Centre Point of Indonesia Di Makassar. Penyusunan perjanjian kerjasama tersebut dibuat oleh Tim Koordinasi Investasi Reklamasi Kawasan Centre Point of Indonesia. Perjanjian kerjasama tersebut disusun berdasarkan dokumen lelang, khususnya mengenai hal-hal yang ditawarkan PT. Yasmin Bumi Asri dalam penawarannya.

Pada prosesnya kemudian terjadi 2 (dua) kali perubahan atau addendum terhadap perjanjian kerjasama tentang reklamasi Kawasan Centre Point of Indonesia Di Makassar tersebut, yakni Addendum Pertama Nomor 515/III/PEMPROV/2015 dan Nomor 255/YBA/III/2015 tertanggal 6 Maret 2015 dan Addendum Kedua Nomor 008/IV/PEM-PKS/2018 dan Nomor 215/YBA/IV/2018 tertanggal 5 April 2018. Addendum Pertama dilakukan oleh karena terbitnya Sertifikat Hak Pakai Pemerintah Provinsi Sulawesi Selatan Nomor 20011/Maccini Sombala dengan luas lahan 12,11 Ha yang merupakan bagian dari kawasan reklamasi sebagaimana disebutkan dalam Perjanjian Kerjasama reklamasi kawasan Centre Point of Indonesia. Untuk itu, maka disepakati oleh para pihak bahwa luas lahan yang akan diberikan kepada Pemerintah Provinsi Sulawesi Selatan berkurang dan menjadi 38,36 Ha.

Sedangkan Addendum Kedua dilakukan untuk menambah luasan kawasan reklamasi yang akan diberikan kepada Pemerintah Provinsi Sulawesi Selatan, yang pada Addendum Pertama berkurang 12,11 Ha dan menjadi 38,36 Ha. Untuk itu, disepakati untuk menambahnya kembali seluas $12,11 \mathrm{Ha}$ dengan menetapkan lokasi baru. Selain itu, Addendum Kedua ini juga dilakukan untuk menambah jangka waktu pelaksanaan reklamasi yang mana pada Addendum Pertama selama kurun waktu 1.700 hari kalender terhitung sejak ditandatanganinya Perjanjian Kerjasama Nomor 
252/VII/PEMPROV/2013 dan Nomor 231/YBA/VII/2013, menjadi 3.080 hari kalender sejak ditandatanganinya Perjanjian Kerjasama Nomor 252/VII/PEMPROV/2013 dan Nomor 231/YBA/VII/2013.

Saat ini pelaksanaan reklamasi pantai losari dalam rangka pembangunan Centre Point of Indonesia masih berlangsung. Pelaksanaan reklamasi tersebut diharapkan dapat memberikan nilai yang bermanfaat bagi masyarakat, khususnya masyarakat Kota Makassar. Reklamasi pantai sesungguhnya adalah upaya untuk pembangunan kota dan pengembangan kawasan, namun demikian perlu untuk memperhatikan dampak yang timbul akibat reklamasi tersebut, khususnya bagi masyarakat nelayan yang mata pencahariannya di pantai dan laut.

Secara umum, reklamasi pantai dapat memberikan manfaat positif seperti menambah luas lahan, pengembangan wisata bahari, penataan wilayah pantai dan pesisir, penyediaan lahan untuk berbagai keperluan, serta pengembangan daerah bahari. Di sisi lain, tidak dapat dipungkiri bahwa reklamasi pantai juga memberikan dampak negatif seperti potensi akan kerusakan ekosistem pesisir, potensi konflik sosial, gangguan mata pencaharian, potensi pencemaran air laut, potensi kerusakan pantai, dan lain-lain sebagainya. Untuk itu, pelaksanaan reklamasi memerlukan perencanaan yang jelas dan konprehensif agar hasil dari reklamasi dapat memberikan manfaat yang besar bagi masyarakat. Reklamasi pantai tidak dapat dijadikan sebagai ajang bisnis untuk meraup keuntungan yang besar karena bagaimanapun tanah hasil reklamasi adalah tanah negara yang merupakan milik Bangsa Indonesia secara utuh dan menyeluruh.

\section{SIMPULAN}

Penggunaan instrumen kontrak dalam pembangunan Centre Point of Indonesia (CPI) di Kota Makassar dimungkinkan oleh Undang-Undang Nomor 30 Tahun 2014 tentang Administrasi Pemerintahan, Undang-Undang Nomor 23 Tahun 2014 tentang Pemerintahan Daerah, dan Undang-Undang Nomor 27 Tahun 2007 jo. Undang-Undang Nomor 1 Tahun 2014 dan Pengelolaan Wilayah Pesisir dan Pulau-Pulau Kecil. Kontrak tersebut adalah kontrak publik karena dilakukan oleh Pemerintah Provinsi Sulawesi Selatan. Pemerintah Provinsi Sulawesi Selatan perlu membuat peraturan daerah atau perubahan atas peraturan daerah yang mengatur tentang pengelolaan wilayah pesisir karena sampai saat ini peraturan daerah yang berlaku adalah Peraturan Daerah Provinsi Sulawesi Selatan Nomor 6 Tahun 2007 tentang Pengelolaan Wilayah Pesisir yang belum disesuaikan dengan Undang-Undang Nomor 23 Tahun 2014 tentang Pemerintahan Daerah. Selain itu, perlu untuk memperhatikan kewenangan yang dimiliki oleh pemerintah provinsi sebagaimana diatur dalam peraturan perundangundangan untuk kemudian disosialisasikan kepada masyarakat agar masyarakat mengetahui dan mengerti batasan kewenangan yang dimiliki pemerintah daerah sehingga dapat meredam konflik antara masyarakat dengan pemerintah. Kegiatan reklamasi yang dilakukan juga harus memperhatikan dampak yang ditimbulkan akibat kegiatan reklamasi tersebut, khususnya dampak lingkungan dan dampak sosial bagi masyarakat nelayan. 


\section{DAFTAR PUSTAKA}

Anshori llyas, et. al. (2017). Kontrak Publik. Makassar: UPT Unhas Press.

Kartini Muljadi dan Gunawan Widjaja. (2008). Perikatan Yang Lahir Dari Perjanjian. Jakarta: PT. RajaGrafindo Persada.

Lutfi Effendi. (2004). Pokok-Pokok Hukum Administrasi. Malang: Bayumedia Publishing. Mariam Darus Badrulzaman. (1994). Aneka Hukum Bisnis. Bandung: Alumni.

Muhammad Ilham Arisaputra. (2005). Reforma Agraria Di Indonesia. Jakarta: Sinar Grafika.

Peter Mahmud Marzuki. (2005) Penelitian Hukum. Jakarta: Kencana.

Slamet Suhartono. (2013). "Desentralisasi Pengelolaan Sumber Daya Alam Untuk Mewujudkan Kesejahteraan Masyarakat" Jurnal Ilmu Hukum, Volume 9 Nomor 18

Subekti. (1996). Hukum Perjanjian. Jakarta: PT. Intermasa.

Wirjono Prodjodikoro. (2004). Asas-asas Hukum Perjanjian. Bandung: Bandar Maju.

Zulkifli Aspan, Ariani Arifin, Anshori llyas, Ahsan Yunus. "Perizinan Pengelolaan Wilayah Pesisir sebagai Kewenangan yang Diderivasi dari Hak Menguasai Negara", AlAzhar Islamic Law Review Vol. 1 (1), 9-25, 2019. 